\title{
Pivotal temperature and sexual dimorphism of Podocnemis expansa hatchlings (Testudines: Podocnemididae) from Bananal Island, Brazil
}

\author{
Adélio Lubiana ${ }^{1} \&$ Paulo Dias Ferreira Júnior ${ }^{1,2}$ \\ 1 Programa de Mestrado em Ecologia de Ecossistemas, Centro Universitário Vila Velha. Rua Comissário José Dantas de Melo \\ 21, Boa Vista, 29102-770 Vila Velha, Espírito Santo, Brasil.E-mail: adelio_lubiana_neto@hotmail.com \\ 2 Corresponding author. E-mail: pdfj@hotmail.com
}

\begin{abstract}
A common problem when trying to identify the sex of hatchling turtles is that juveniles are not obviously externally dimorphic and current techniques to identify sex are often invasive. In this paper, 300 eggs of Podocnemis expansa from Bananal Island, state of Tocantins (Brazil), were incubated at constant temperatures. The carapaces of the hatchlings were photographed and subjected to geometric morphometric analysis. The hatchlings were subsequently euthanized and had their gonads removed for sex determination. The pivotal temperature of $P$. expansa was $33.5^{\circ} \mathrm{C}$, confirming that this species has the highest pivotal temperature among reptiles. Geometric morphometric analysis of the shape of the carapace proved efficient in differentiating the sex of the hatchlings and confirmed that this methodology can be efficient for studies that need to ascertain the sex ratio in P. expansa hatchlings.
\end{abstract}

KEY WORDS. Carapace; incubation; morphometry; sex ratio; giant Amazon River turtle.

Reptiles generally have two basic mechanisms of sex determination: one is genotypic, the other one is environmentally driven (VALENZuela \& LANCE 2004). In turtles, as a rule, high egg incubation temperatures result in a female brood, whereas low incubation temperatures result in a male brood. The giant Amazon River turtle, Podocmemis expansa (Schweiger, 1812), is no exception (AlHo et al. 1984, VALENZUela et al. 1997, VAlENZUELA 2001). At a given incubation threshold, called pivotal temperature (BuLL 1980), an equal proportion of males and females are produced. Different proportions of males and females result from incubation temperatures above and below this threshold (PIEAU 1996), often referred to as transition zones. The extent of the transition zones, corresponding to $1^{\circ} \mathrm{C}$ above and below the pivotal temperature in P. expansa (AlHo et al. 1984), varies between species.

Species with temperature-based sex determination and a broad geographic distribution often compensate for variations in climate by adjusting their pivotal temperature (EWERT \& NELSON 1991, EwERT et al. 1994, 2004). This is necessary in order to maintain breeding populations, as failure to adjust the pivotal temperature would result in a one-sexed local generation in the borderline of the species' distribution, precluding further reproduction in newly colonized areas (Bull et al. 1982, EwERT et al. 1994).

An assessment of the pivotal temperature in different populations of de $P$. expansa is important to help understand the evolution of sex determination mechanisms of Neotropical turtles (Janzen \& Krenz 2004, ValenZuela 2004). A few studies have been previously conducted. On the beaches of Rio Trombetas, where temperatures are often variable, the pivotal temperature of $P$. expansa was $34.5^{\circ} \mathrm{C}$ (AlHo et al. 1984). An- other experiment, conducted with eggs collected from the Caquetá River, Colombia, and reared in captivity under constant temperatures, revealed a pivotal temperature of $32.6^{\circ} \mathrm{C}$ for the same species. Valenzuela et al. (1997) and Malvasio et al. (2002a) confirmed the sex determination mechanism of $P$. expansa in the Bananal Island, Tocantins, but failed to determine the pivotal temperature of the species in this location.

Identifying the sex of $P$. expansa hatchlings is difficult because juveniles are not obviously externally dimorphic. Consequently, previous studies have relied on invasive methods to determine the sex of the hatchlings, often killing the animals. Amongst these methods are the histological or anatomical scrutiny of the sex organs (AlHo et al. 1984, Malvasio et al. 2002b), radioimmunoassay (RIE) tests to measure blood testosterone levels (Lance et al. 1992, Rostal et al. 1994, Valenzuela et al. 2004) and laparoscopy (WyNEKen et al. 2007). In a search for non-invasive alternative methods of sex determination for hatchlings of P. expansa (Hildebrand et al. 1997) and Lepidochelys olivacea (Eschscholtz, 1829) (MicheL-Morfin et al. 2001), researchers resorted to conventional morphometric analysis. This laborious method that employs several linear measurements, however, is prone to error due to the minuscule size of the hatchlings

Geometric morphometric (GM) methods have been applied with success to ascertain the sex of $P$. expansa hatchlings (VAlenzuela et al. 2004). GM methods allow the detection of subtle differences between the sexes right after eclosion. Unlike traditional morphometry, which uses linear distances, GM evaluates the entire carapace landscape through points of biological correspondence. Using GM, VALENZuela et al. (2004) were 
able to correctly identify the sex of $P$. expansa and Chrysemys picta (Schneider, 1783) hatchlings with 90\% and 98\%accuracy, respectively. In order to confirm the accuracy of the method, histological analysis of the gonads was performed.

This research had two goals. First, we endeavored to ascertain the pivotal temperature of $P$. expansa from eggs collected on the beaches of the Bananal Island, State of Tocantins (Brazil). Second, in order to establish a feasible and non-invasive method of sex determination for the population under study, we used GM methods to search for sexual dimorphism in the carapace of the hatchlings.

\section{MATERIAL AND METHODS}

Eggs were collected in September 2006 from 10 nests in the Canguçu beach ( $\left.5^{\circ} 31^{\prime} \mathrm{S}, 50^{\circ} 05^{\prime} \mathrm{W}\right)$, located on the right side of the Javaés River, Bananal Island, Tocantins. Thirty eggs were taken from each nest, totaling 300 eggs. Eggs were collected in the morning of the same day they were laid, to avoid desiccation. Once collected, eggs were placed into plastic boxes containing moist vermiculite $(1 \mathrm{~g} / 1 \mathrm{ml})$ and transported to the laboratory in Vitória (ES). The transportation of the eggs took place during the first two days after oviposition, which corresponds to the best period for their manipulation (Malvasio et al. 2005).

In the laboratory, the eggs were distributed among ten incubators, each holding 30 eggs. In order to avoid parental characteristics to prevail over incubation effects (clutch effect), three eggs from each nest were mixed in each of the incubators. Incubator temperatures were adjusted between $28^{\circ} \mathrm{C}$ e $37^{\circ} \mathrm{C}$, with a difference of $1^{\circ} \mathrm{C}$ between incubators. The temperature was maintained constant with the help of an analogical thermostat with a $0.1^{\circ} \mathrm{C}$ precision, placed inside the incubators. Eggs were incubated in moist vermiculite $(1 \mathrm{~g} / 1 \mathrm{ml})$. Eclosion success was calculated as a ratio between the total number of eggs and the number of hatchlings from each incubator. Incubation duration was calculated between oviposition and eclosion of the eggs. Eclosion was defined as the moment when the hatchlings break up the egg.

I order to ascertain the relationship between sex dimorphism and carapace shape we used GM methods previously employed by Valenzuela et al. (2004) and Myers et al. (2006). For our analyses we quantified carapace shape in the following manner. First, digital images of the carapace of each hatchling, photographed during its first two weeks of life after complete absorption of the vitelum, were obtained using a Sony DSCS600 placed perpendicularly to and $25 \mathrm{~cm}$ above the subject. An image file was then obtained with the software TpsUtil (Rolph 2005). Subsequently, anatomical landmarks were recorded using TpsDig software (Rolph 2006a). A total of 26 type 1 and four type 2 anatomical landmarks were employed (Figs 1 and 2), following the classification of Bookstern (1991). Type 1 landmarks are formed by the intersections between the lines delineating the vertebral, lateral and marginal scutes; type 2 landmarks include the invaginations of the outer portion of the marginal scutes of the neck (anterior) and anal regions (posterior). Hatchlings that displayed anomalies in the carapace, such as discrepant number of scutes, were excluded from the morphometric analysis, but included in the determination of the pivotal temperature.

The anatomical landmarks of all individuals were superimposed in TPSRelw (RolPH 2006b) to generate a consensus. Procrustes distance analysis was then used to evaluate the similarities between shapes and mathematically remove the effects of digitizing position, orientation, and scale. From the aligned anatomical landmarks, a W-matrix was calculated as partial warp scores from the thin-plate spline (TPS) (MonTEIRo \& ReIs 1999).
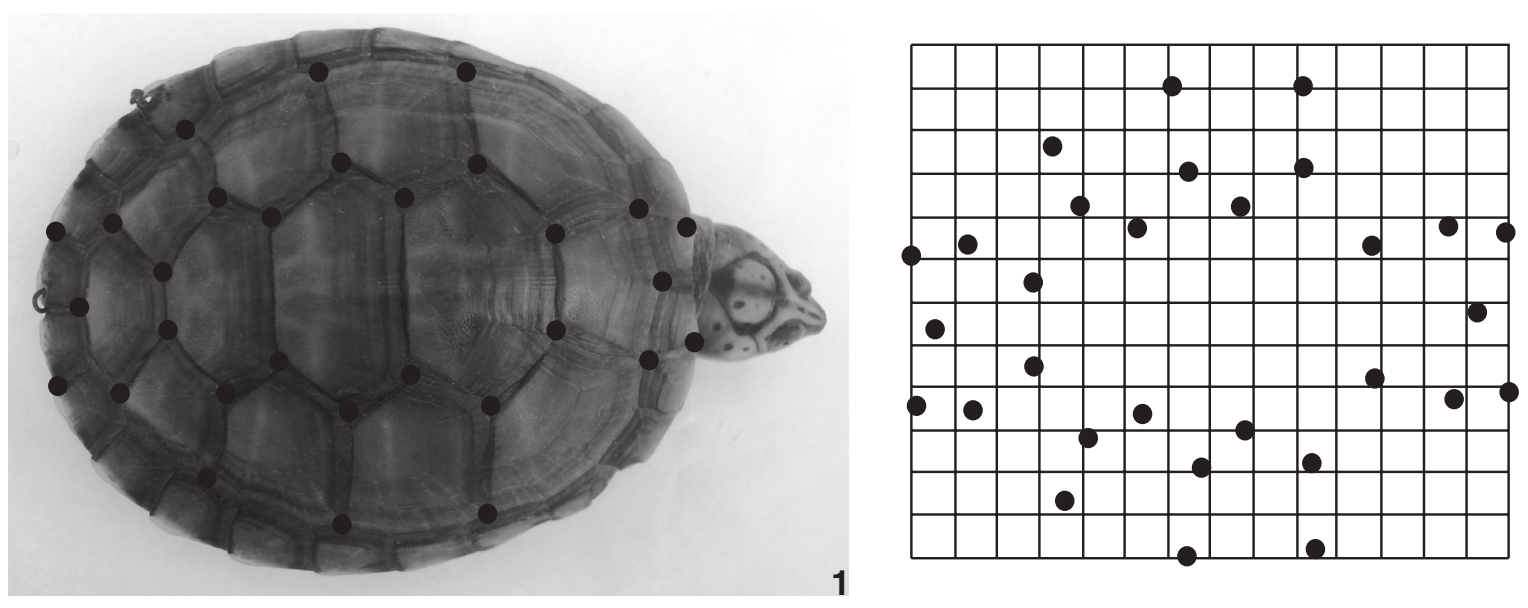
1

Figures 1-2. Anatomical landmarks used in the geometric morphometric analysis of the 92 hatchlings of Podocnemis expansa shortly after eclosion (1) and the consensus generated by the superposition of the carapaces of all hatchlings (2). 
Using the shape data described above, morphological variation was assessed in the following manner. First, we performed a multivariate analysis of variance (MANOVA) over the W-matrix using the program TpsRegr (RoLPH 2005), in order to determine whether there were differences in carapace shape between the sexes (i.e., sexual dimorphism). Second, we used the program TpsRewl to generate deformation grids (Tps function) to facilitate the visualization of shapes and the direction and magnitude of the differences between the carapaces. Finally, we used multivariate regression to calculate the percentage of variation due to sex, using the software TpsRegr. In order to evaluate the percentage of correct sex allocation, we performed permutation and cross-validation tests using the software Statistica 6.0.

The correct sex classification was observed by contrasting the estimated sex with the true sex as assigned by gonadal inspection, which was performed as described below. First, one month old hatchlings were killed with an intra-cardiac injection of Thiopental Sodium (1g). Second, the plastron of each specimen together with the stomach, intestines and liver were removed with a surgical scissors to allow the visualization of the gonads. Each pair of gonads was subsequently stored together with the kidneys in a container filled with $10 \%$ formaline. Third, the gonads were embedded in paraffin, sliced with the help of a microtome and colored with hematoxylineosin for slide preparation. Sex determination was then conducted in all hatchlings as outlined in MaLvasio et al. (2002b).

\section{RESULTS}

The pivotal temperature for the population of $P$. expansa under study (Rio Javaés, Bananal Island) was $33.5^{\circ} \mathrm{C}$ (Fig. 3). A total of 96 hatchlings from 10 incubators were used in this calculation. A sudden drop in eclosion success happened below $29^{\circ} \mathrm{C}$ and above $36^{\circ} \mathrm{C}$, suggesting that these temperatures correspond to thresholds above and below which the embryos

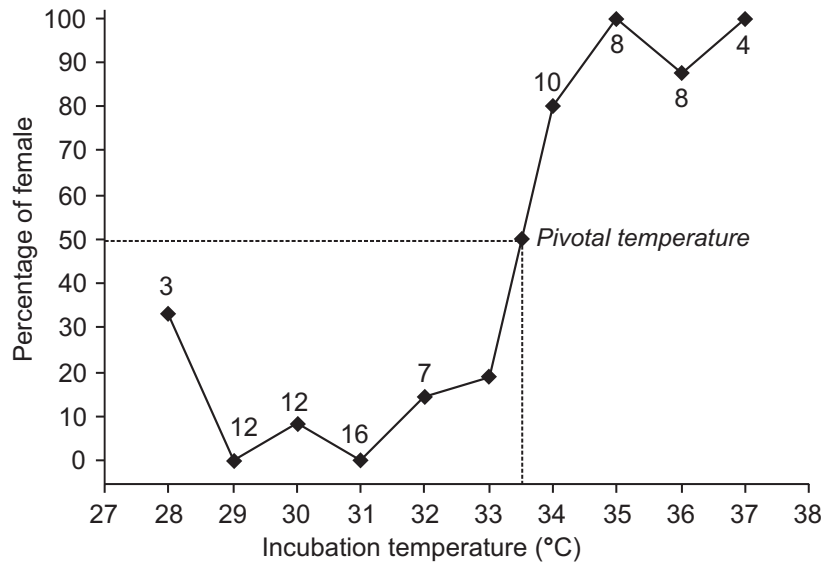

Figure 3. Percentage of Podocnemis expansa females resulting from each incubation temperature. The pivotal temperature $\left(33.5^{\circ} \mathrm{C}\right)$ is clearly marked. The numbers indicate the sample size.

cannot survive (Tab. I). A positive correlation between duration and temperature of incubation $\left(\mathrm{r}^{2}=0.848, \mathrm{p}<0.01\right)$ was found in this study.

Examining carapace shape variation of hatchlings of $P$. expansa using MANOVA, we found significant effects for sex ( $\mathrm{F}=10.85, \mathrm{p}<0.01)$. Using cross-validation analysis, we found that $84.3 \%$ of hatchlings were correctly classified. Sex differences were responsible for $10.8 \%$ of the carapace shape variation. Principal component analysis revealed overlap in shape space for several specimens, what rendered impossible a complete separation between the sexes of these individuals (Fig. 4).

In general terms, the carapace shapes of male and female hatchlings of $P$. expansa from the Bananal Island were similar to the shapes described by Valenzuela et al. (2004) for the population in Colombia (Figs 5-8). With respect to sexual dimorphism, males from both places displayed relative more

Table I. Relationship between incubation temperature and sex ratio in $P$. expansa. Total individuals sexed (n). Duration of incubation: mean \pm standard error. Number of males and females resulting from each temperature, with relative percentage for each sex.

\begin{tabular}{crccccc}
\hline Temperature $\left({ }^{\circ} \mathrm{C}\right)$ & $\mathrm{n}$ & Duration of incubation (days) & Male (\%) & Female (\%) & Eclosion success (\%) \\
\hline 28 & 3 & $78.3 \pm 14.47(69-95)$ & $2(66.7)$ & $1(33.3)$ & 10 \\
29 & 12 & $75.6 \pm 7.74(61-83)$ & $12(100)$ & 0 & 71 \\
30 & 12 & $62.8 \pm 8.38(50-68)$ & $11(91.7)$ & 1 & $(8.3)$ & 70 \\
31 & 16 & $55.8 \pm 5.83(45-60)$ & $16(100)$ & 0 & $1(14.3)$ & 43 \\
32 & 7 & $46.4 \pm 5.53(38-51)$ & $6(85.7)$ & $13(81.2)$ & $3(18.8)$ & 76 \\
33 & 16 & $46.1 \pm 5.60(38-53)$ & $2(20.0)$ & $8(80.0)$ & 55 \\
34 & 10 & $39.8 \pm 5.69(35-47)$ & 0 & 8 & $(100)$ & 50 \\
35 & 8 & $37.7 \pm 4.41(34-43)$ & $1(12.5)$ & $7(87.5)$ & $4(100.0)$ & 13 \\
36 & 8 & $36.5 \pm 3.42(33-41)$ & 0 & & 48 \\
\hline
\end{tabular}



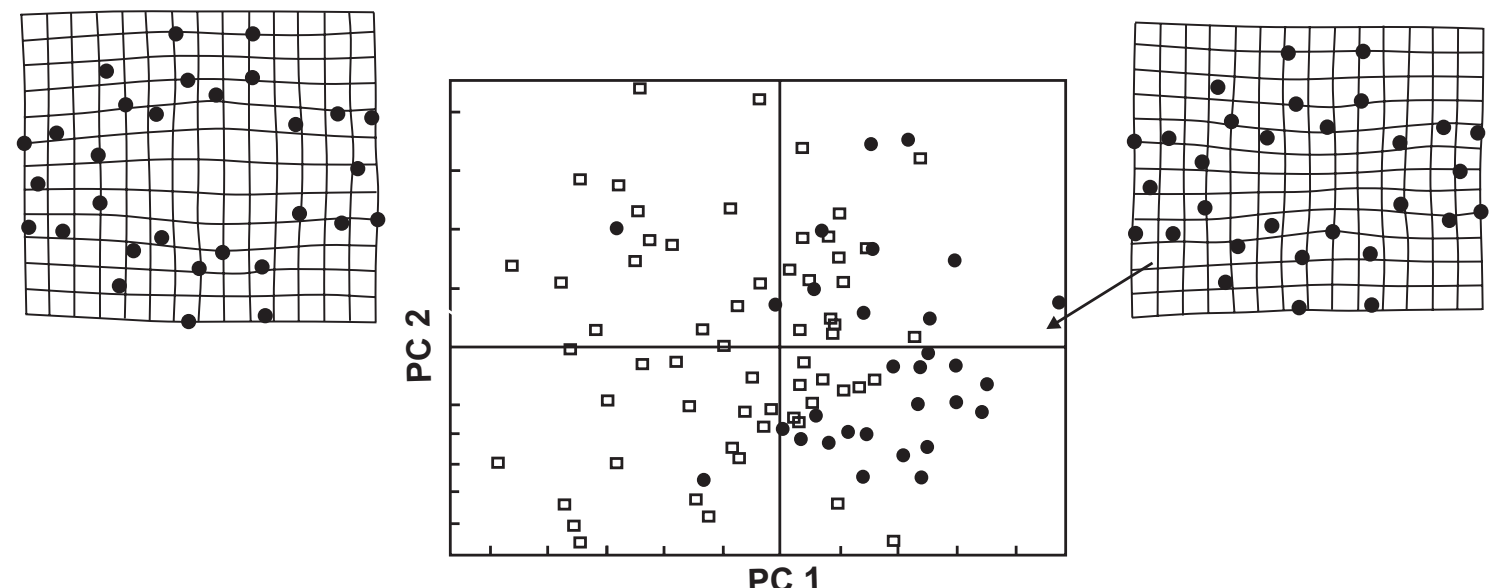

Figure 4. Representatio $\mathrm{n}$ of the first axes of the principal component analysis of the shape of the carapace of the 92 hatchlings of Podocnemis expansa shortly after eclosion. PC1 explains $30.1 \%$ of the variation in shape and PC2 explains $24.1 \%$. Circles represent females and squares represent males. The deformation grid predicted for the males is on the left hand side, and for the females, on the right hand side. The head of the hatchlings is on the left hand side of the deformation grid.
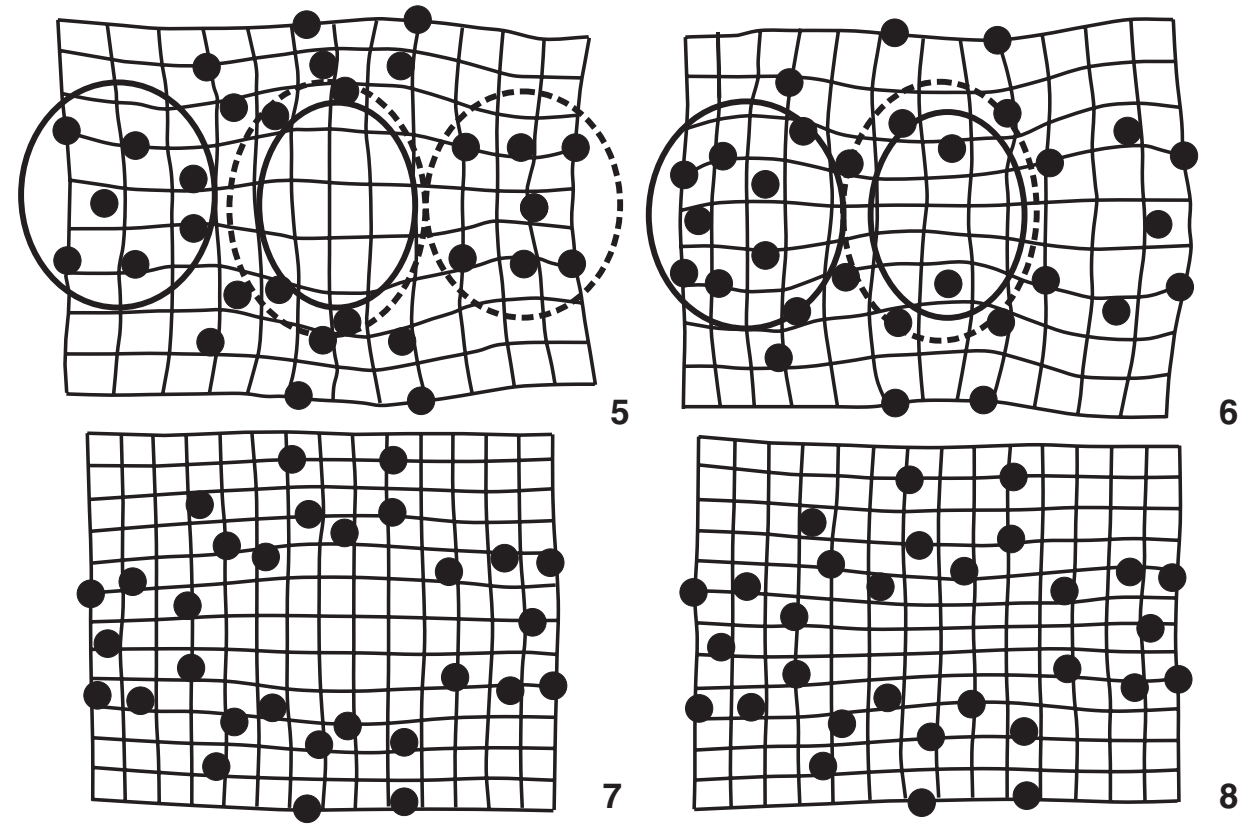

Figures 5-8. Comparison between the deformation grids of males and females of Podocnemis expansa from Colombia (VALENZUELA et al. 2004) and Bananal Island: (5) male from Colombia; (6) female from Colombia - the circles represent the areas where the differences are more accentuated; (7) Male from Bananal Island; (8) female from Bananal Island - the head of the hatchlings is on the right hand side of the deformation grid.

expansion of the central vertebral region of the carapace relative to females. In the latter, the anatomical marks of the center of the carapace are grouped more closely together, the vertebral scutes are narrower and the lateral scutes are wider than in the former. When comparing the populations from the
Bananal Island with populations from Colombia, however, a difference in the anal region of the carapace, which is more compressed in males from the Bananal Island, was discerned. In contrast with the hatchlings from Colombia, with males and females presenting differences in the marginal scutes near 
the head and neck plates, hatchlings from the Bananal Island did not show significant dimorphism in this region. In males from Colombia, the caudal region of the carapace is wider and the frontal region is narrower with respect to females. In contrast, no sexual dimorphism was encountered in either region (anterior and posterior) of the carapace of hatchlings from the Bananal Island. In summary, the main sexual differences in the hatchlings from Brazil are in the central region of the carapace: the females are more round and dome-shaped and males tend to have a more elongated and flattened carapace.

\section{DISCUSSION}

The pivotal temperature found in this research for $P$. expansa was $33.5^{\circ} \mathrm{C}$, in-between the pivotal temperatures for populations of Rio Trombetas, Pará $\left(34.5^{\circ} \mathrm{C}\right.$ : AlHo et al. 1984) and Rio Caquetá, Colômbia $\left(32.6^{\circ} \mathrm{C}\right.$ : Valenzuela 2001). Nevertheless, these differing results must be interpreted with caution, as they could be due to differing methodologies used in the various studies, as for example in-situ incubation versus laboratory incubation. Independent from these considerations, however, the pivotal temperature of $P$. expansa is the highest ever recorded for a reptile (Valenzuela \& Lance 2004). Another turtle that nesting on the same beaches as P. expansa (SouzA \& Vogt 1994), Podocnemis unifilis (Troschel, 1848), also has a high pivotal temperature $\left(\mathrm{ca} .32^{\circ} \mathrm{C}\right)$. The high pivotal temperature of $P$. expansa may be due to the fact that this tropical species (Pritchard \& Trebbau 1984) nests on open and sandy beaches that are mainly devoid of vegetation (FerReira Júnior \& CASTro 2003). The resulting high incubation temperatures determine the need for high pivotal temperatures in order to avoid female-biased that would prevent further reproduction. High temperatures also determine shorter incubation duration, which turns out to be essential to eclosion success in the natural environment under study. In fact, one of the major causes of viable turtle nest losses in fluvial beaches is nest flooding (EsCALONA \& Fa 1998, Páez \& Bock 1998 Pezzuti \& Vogt 1999). For both $P$. expansa and $P$. unifilis, the timing of the wet season and consequent raise in the water levels of the Brazilian northern and mid-western rivers can be decisive for the survival of the embryos and hatchlings (Alho \& PÁdua 1982, Ferreira Júnior \& CASTRo 2003, 2005). Higher temperatures shorten the length of incubation, allowing embryogenesis to complete before the floods come (FERREIRA JúNIOR \& CASTRo 2006).

In spite of the fact that $P$. expansa has a continuous distribution (even if irregularly so) along the shores of the Amazonas, Orinoco and Tocantins-Araguaia rivers (PRITCHARD \& Trebbau 1984), genetic differences between populations in Brazil, Peru and Colombia (Valenzuela 2001, Bock et al. 2001) have been found. Differences in allele frequencies allow for the separation between populations in the north and south of the Araguaia River (SITES JR et al. 1999). Interplay between climatic and genetic differences along the wide geographic range of $P$. expansa may be responsible for the different pivotal tem- peratures, which guarantee a balanced sex ratio of the hatchlings. The estimation of the pivotal temperature in the different populations of $P$. expansa is essential to guarantee success in management and conservation efforts, and may be an important factor to consider when giving priority to certain conservation areas.

As expected, a larger percentage of females resulted from higher incubation temperatures, whereas, males were more abundant when incubation temperatures were lower. Contrary to expectations, however, this relationship was not always precise: temperatures of $36^{\circ} \mathrm{C}$ and $30^{\circ} \mathrm{C}$, for example, resulted in a mixed brood. The low hatching success below $29^{\circ} \mathrm{C}$ and above $36^{\circ} \mathrm{C}$ ( $10 \%$ e $13 \%$ respectively) can be attributed to the species' thermal limits and are seldom reached in the open sandy beaches where P. expansa nests (Ferreira Júnior \& Castro 2006).

In agreement with previous results (VALENZuela et al. 2004), we were able to uncover sexual dimorphism in the external morphology of P. expansa hatchlings using GM methods. Additionally, some resemblances between the carapaces of the hatchlings in this study and those from Colombia were found. It was established that the central portion of the carapace, where the vertebral scutes are located, is the region where most sex dimorphism can be detected in both populations. In spite of this similarity, however, both populations did not fully agree in the whole spectrum of their carapace dimorphism: Brazilian hatchlings did not exhibit sexual dimorphism in the vertebral and lateral scutes near the cloaca and the neck, as did the hatchlings from Colombia.

Only a small portion of the carapace shape can be explained by sex (10.8\%). The remaining $89.2 \%$ may be attributed to variables such as multiple paternity, (VALENZUELA 2000), genetic influences (VALENZUela 2001), as well as differing incubation temperatures (higher temperatures determine faster development; YnTema \& Mrosovsky 1982). Besides affecting gonadal differentiation, incubation temperatures may influence embryonary development which in turn reflects in the shape of the carapace (STANDING et al. 1999). The differences in carapace morphology found between populations of $P$. expansa from the Caquetá River, Colombia, and Javaés River, Brazil, did not come as a surprise, as these populations are separated by ca. $2500 \mathrm{~km}$. Nonetheless, these differences enrich our results as they provide one more indication that GM may be suitable for population differentiation as well as sex differentiation. A similar conclusion had been reached by MYers et al. (2006) who were able to discriminate between two populations of Trachemys scripta (Schoepff, 1792), separated by less than $5 \mathrm{~km}$, based on the shape of the plastron using GM methods. In conclusion, our results suggest that, in addition to metapopulation structure (Sites Jr et al. 1999, Bоск et al. 2001), the carapace shape variation of $P$. expansa (VAlEnzuela et al. 2004 and this study) may provide a feasible, non-invasive and cheap method to differentiate between populations, what can be very useful in ecological studies. 


\section{ACKNOWLEDGEMENTS}

We thank the Centro Universitário Vila Velha (UVV) and the Universidade Federal do Tocantins (UFT), specially Adriana Malvasio, for the infra-structure of the Centro de Pesquisas Canguçu. We also thank Leandro Monteiro for his help with the Morphometric Analysis and Marcelo Renan de Deus Santos, Tayse Domingus de Souza and Carlos Roberto for their help with histological analysis. The UFT students Kennedy Mota, Mauro Resende, Tiago Portelinha, Pompeu Mendes, Leila Paula, Marcílio Ferreria, Deyla Paula, Lílian Raquel, Liana Bezerra and Eduardo Ferreira helped collecting eggs and students from the UVV, Rodrigo Barcelos, Rodrigo Teófilo and Lauana Schneider, helped with egg incubation and histological analysis.

\section{LITERATURE CITED}

Alho, C.J.R. \& L.F.M. PÁduA. 1982. Sincronia entre o regime de vazante do rio e o comportamento de nidificação da tartaruga da Amazônia Podocnemis expansa (Testudinata: Pelomedusidae). Acta Amazonica 12 (2): 323-326.

Alho, C.J.R.; T.M.S. DAnn \& L.F.M. PÁdua. 1984. Influência da temperatura de incubação na determinação do sexo da tartaruga-da-amazônia Podocnemis expansa (Testudinata: Pelomedusidae). Revista Brasileira de Biologia 44 (3): 305-311.

Bock, B.C.; V.P. PÁEz \& M.M. White. 2001. Genetic population structure of two threatened south american river turtle species, Podocnemis expansa and Podocnemis unifilis. Chelonian Conservation and Biology 4 (1): 47-52.

BooksteIn, F.L. 1991. Morphometric tools for landmark data: geometry and biology. Cambridge, Cambridge University Press, XVII+455p.

BulL, J.J. 1980. Sex determination in reptiles. Quarterly Review of Biology 55 (1): 3-21.

Bull, J.J.; R.C. Vogt \& C.J. McCoy. 1982. Sex determining temperatures in turtles: a geographic comparison. Evolution 33: 326-332.

Escalona, T. \& J.E. FA. 1998. Survival of nests of terecay turtle (Podocnemis unifilis) in the Nichare-Tawadu Rivers, Venezuela. Journal of Zoology 244: 303-312.

Ewert, M.A. \& C.E. Nelson. 1991. Sex determination in turtles: diverse patterns and some possible adaptive values. Copeia 1991 (1): 50-68.

Ewert, M.A.; D.R. Jackson \& C.E. Nelson. 1994. Patterns of temperature-dependent sex determination in turtles. Journal of Experimental Zoology 270 (1): 3-15.

Ewert, M.A.; C.R. Etchberger \& C.E. Nelson. 2004. Turtle sex determining modes and TSD patterns, and some TSD pattern correlates, p. 21-32. In: N. Valenzuela \& V.A. LANCE (Eds). Temperature dependent sex determination in vertebrates. Washington, Smithsonian Books, 194p.

Ferreira Júnior, P.D. \& P.T.A. Castro. 2003. Geological control of Podocnemis expansa and Podocnemis unifilis nesting areas in Rio Javaés, Bananal Island, Brazil. Acta Amazonica 33 (3): 445-468.
Ferreira Júnior, P.D. \& P.T.A. Castro. 2005. Nest placement of the giant river turtle, Podocnemis expansa, in the Araguaia River, Goiás State, Brazil. Ambio 34 (3): 212-217.

Ferreira Júnior, P.D. \& P.T.A. CASTRo. 2006. Thermal environment characteristics of Podocnemis expansa and Podocnemis unifilis nesting areas on the Javae's River, Tocantins, Brazil. Chelonian Conservation and Biology 5 (1): 102-107.

Hildebrand, V.P.; N. Bermúdez \& M.C. Peñuela. 1997. La tortuga charapa (Podocnemis expansa) en el río Caquetá, Amazonas, Colombia. Aspectos de su biología reproductiva y técnicas para su manejo. Santafé de Bogotá, Disloque Editores, $152 \mathrm{p}$.

Janzen, F.J. \& J.G. Krenz. 2004. Phylogenetics: which was first, TSD or GSD? p. 121-130. In: N. ValenZuela \& V.A. LANCE (Eds). Temperature dependent sex determination in vertebrates. Washington, Smithsonian Books, 194p.

LANCE, V.A.; N. Valenzuela \& V.P. Hildedrand. 1992. A hormonal method to determine sex of hatchling giant river turtles, Podocnemis expansa: application to endangered species. Journal of Experimental Zoology 270: 16A.

Malvasio, A.; A.M. Souza; Ferreira Júnior, P.D.; E.S. Reis \& F.A.A. SAmpaio. 2002a. Temperatura de incubação dos ovos e granulometria dos sedimentos das covas relacionadas a determinação sexual em Podocnemis expansa (Schweigger, 1812) e P. unifilis (Troschel, 1848) (Testudines, Pelomedusidae). Publicações Avulsas do Instituto Pau Brasil de História Natural 5: 11-25.

Malvasio, A.; A.M. Souza; E. Schlennz; G. Salera Júnior \& F.A.A. SAMPAIO. 2002b. Morfologia dos órgãos reprodutores de recém-eclodidos de Podocnemis expansa (Schweigger, 1812) e P. unifilis (Troschel, 1848) (Testudines, Pelomedusidae). Publicações Avulsas do Instituto Pau Brasil de História Natural 5: 27-37.

Malvasio, A.; A.M. Souza; E. Schlennz; G. Salera Júnior \& F.A.A. SAMPaIo. 2005. Influência da manipulação dos ovos no sucesso das eclosões e no padrão normal de escutelação do casco em Podocnemis expansa (Schweigger, 1812) e P. unifilis (Troschel, 1848) (Testudines, Pelomedusidae). Publicações Avulsas do Instituto Pau Brasil de História Natural 8-9: 39-52.

Michel-Morfin, J.E.; V.M. Gómez Muñoz \& C. Navarro Rodríguez. 2001. Morphometric model for sex assessment in hatchling olive Ridley Sea Turtles. Chelonian Conservation Biology 4 (1): 53-58.

Monteiro, L.R. \& S.F. Reis. 1999. Princípios de morfometria geométrica. Ribeirão Preto, Holos Editora, 188p.

Myers, E.M.; F.F. Janzen; D.C. Adams \& J.K. Tucker. 2006. Quantitative genetics of plastron shape in slider turtles (Trachemys scripta). Evolution 60 (3): 563-572.

PÁzz, V.P. \& B.C. Bock. 1998. Temperature effect on incubation period in the yellow-spotted river turtle, Podocnemis unifilis, in the Colombian Amazon. Chelonian Conservation and Biology 3 (1): 31-36. 
Pezzuti, J.C.B. \& R.C. Vogt. 1999. Nesting ecology of Podocnemis sextuberculata (Testudines, Pelomedusidae) in the Japurá River, Amazonas, Brazil. Chelonian Conservation and Biology 3 (3): 419-424.

PIEAU, C. 1996. Temperature variation and sex determination in reptiles. BioEssays 18 (1): 19-26.

Pritchard, P.C.H. \& P. Trebbau. 1984. The turtles of Venezuela. Caracas, Society for the Study of Amphibians and Reptiles, 403p.

RoLHF, F.J. 2005. TpsUtil for Windows version 1.38. Department of Ecology and Evolution, State University of New York, Stony Book. 2005. Available online at: http://life.bio.sunysb.edu/ morph [Accssed: 28/XII/2006].

Rolhf, F.J. 2006a. TpsDig2 for Windows version 2.10. Department of Ecology and Evolution, State University of New York, Stony Book. Available online at: http:// life.bio.sunysb.edu/morph/. [Accssed: 28/XII/2006].

Rolhf, F.J. 2006b. TpsRelw for Windows version 1.44. Department of Ecology and Evolution, State University of New York, Stony Book. Available online at: http:// life.bio.sunysb.edu/morph/. [Accssed: 28/XII/2006].

Rostal, D.C.; J.S. Grumbles; V.A. Lance \& J.R. Spotila. 1994. Nonlethal sexing techniques for hatchling and immature Desert Tortoises (Gopherus agassizii). Herpetological Monographs 8 (1): 72-82.

Sites Jr, J.W.; N.N. Fitzsimmons; N.J. Silva \& V.H. Cantarelli. 1999. Conservation genetics of the giant amazon river turtle (Podocnemis expansa; Pelomedusidae) - inferences from two classes of molecular markers. Chelonian Conservation and Biology 3 (3): 454-463.

SouZA, R.R. \& R.C. Vogt. 1994. Incubation temperature influences sex and hatchling size in the neotropical turtle Podocnemis unifilis. Journal of Herpetology 28 (4): 453-464.

Standing, K.L.; T.B. Herman \& I.P. Morrison. 1999. Nesting ecology of Blanding's turtle (Emydoidea blandingii) in Nova Scotia, the northeastern limit of the species' range. Canadian Journal of Zoology 77 (10): 1609-1614.

Valenzuela, N. 2000. Multiple paternity in side-neck turtles Podocnemis expansa: evidence from microsatellite DNA data. Molecular Ecology 9 (1): 99-106.

VAlenzuela, N. 2001. Constant, shift, and natural temperatures effects on sex determination in Podocnemis expansa turtles. Ecology 82 (11): 3010-3024.

VALENZUELA, N. 2004. Evolution and maintenance of temperaturedependent sex determination. p. 131-147. In: N. VALENZuela $\&$ V.A. LANCE (Eds). Temperature dependent sex determination in vertebrates. Washington, Smithsonian Books, 194p.

Valenzuela N. \& V.A. Lance. 2004. Temperature dependent sex determination in vertebrates. Washington, Smithsonian Books, 194p.

Valenzuela, N.; E. Martínez \& R. Botero. 1997. Field study of sex determination in Podocnemis expansa from Colombian Amazonia. Herpetologica 53 (3): 390-398.

Valenzuela, N.; D.C. Adams; R.M. Bowden \& A.C. Gauger. 2004. Geometric morphometric sex estimation for hatchling turtles: a powerful alternative for detecting subtle sexual shape dimorphism. Copeia 2004 (4): 735-742.

Wyneken, J.; S.P Epperly; L.B. Crowder; J. Vaughan \& K.B. Esper. 2007. Determining sex in posthatling logghead sea turtles using multiple gonadal accessory duct characteristics. Herpetologica 63 (1): 19-30.

YNTEMA, C.L. \& N. Mrosovsky, N. 1982. Critical periods and pivotal temperatures for sexual differentiation loggerhead sea turtles. Canadian Journal of Zoology 60 (5): 1012-1016.

Submitted: 01.XI.2008; Accepted: 14.IX.2009.

Editorial responsibility: Lucélia Donatti 